\title{
Decavanadate effects in biological systems
}

\author{
Manuel Aureliano *, Ricardo M.C. Gândara \\ CBME, Dept. Química e Bioquímica, FCT, Universidade do Algarve, 8005-139 Faro, Portugal
}

Received 27 January 2005; received in revised form 23 February 2005; accepted 25 February 2005

Available online 23 March 2005

\begin{abstract}
Vanadium biological studies often disregarded the formation of decameric vanadate species known to interact, in vitro, with high-affinity with many proteins such as myosin and sarcoplasmic reticulum calcium pump and also to inhibit these biochemical systems involved in energy transduction. Moreover, very few in vivo animal studies involving vanadium consider the contribution of decavanadate to vanadium biological effects. Recently, it has been shown that an acute exposure to decavanadate but not to other vanadate oligomers induced oxidative stress and a different fate in vanadium intracellular accumulation. Several markers of oxidative stress analyzed on hepatic and cardiac tissue were monitored after in vivo effect of an acute exposure (12, $24 \mathrm{~h}$ and $7 \mathrm{days})$, to a sub-lethal concentration ( $5 \mathrm{mM} ; 1 \mathrm{mg} / \mathrm{kg}$ ) of two vanadium solutions ("metavanadate" and "decavanadate"). It was observed that "decavanadate" promote different effects than other vanadate oligomers in catalase activity, glutathione content, lipid peroxidation, mitochondrial superoxide anion production and vanadium accumulation, whereas both solutions seem to equally depress reactive oxygen species (ROS) production as well as total intracellular reducing power. Vanadium is accumulated in mitochondria in particular when "decavanadate" is administered. These recent findings, that are now summarized, point out the decameric vanadate species contributions to in vivo and in vitro effects induced by vanadium in biological systems.
\end{abstract}

(C) 2005 Elsevier Inc. All rights reserved.

Keywords: Decavanadate; Oxidative stress; Myosin; SR calcium pump

\section{Introduction}

Vanadium was found in commercial ATP and rediscovered for biology as a muscle inhibitor factor (MIF) and $\mathrm{Na}^{+}, \mathrm{K}^{+}$-ATPase inhibitor [1-3]. Currently, vanadium is used as inhibitor of E1-E2 ion transport ATPases [4] being a useful tool to mimics the transition states of phosphoryl transfer reactions [5]. It has been reported that vanadate reverses drug resistance [6,7], increases glucose metabolism [8] and influences the activity of several enzymes, either inhibiting or stimulating [9-11]. Recent data associated vanadium essentially to the treatment of diabetes, due to its insulin mimetic

\footnotetext{
${ }^{*}$ Corresponding author. Tel.: +351 289 800900; fax: +351 289 819403.

E-mail address: maalves@ualg.pt (M. Aureliano).
}

properties [12-14] and to the prevention of animal carcinogens $[15,16]$, however some studies of D'Cruz and its collaborators have reported spermicidal and antiHIV activity of vanadium compounds [17].

Despite its toxicity at higher concentrations, vanadium is assumed to be an essential element for organisms [18,19], although its biological role is far from a clear identification. In cells, oxovanadium(IV) species are essentially the vanadium species present, even though some of the interest in vanadium metallobiochemistry is probably due to the similarities between the phosphate and vanadate chemistries in solution. In that sense, a good number of the biochemical importance of vanadium is associated with the +5 oxidation state (vanadate) [9]. However, in vanadium $(+5)$ solutions different oligomeric $(n=1-10)$ vanadate anionic species can occur simultaneously in equilibrium such 
as monomeric $\left(\mathrm{V}_{1}\right)$, dimeric $\left(\mathrm{V}_{2}\right)$, tetrameric $\left(\mathrm{V}_{4}\right)$ and decameric $\left(\mathrm{V}_{10}\right)$ species [20]. These vanadate species are known to interact with many proteins besides affecting biological mechanisms $[9-11,21,42]$.

Among the vanadate oligomers, decavanadate as been referred of biochemical importance and is considered the major protein-bound species. In the last 10 years, reported decavanadate studies includes the possibility to be used as a tool in the understanding of molecular mechanism of muscle contraction [22], an inhibitor of several ATPases such as P-type ATPases (E1/E2ATPases), ABC-ATPases and ribonucleases suggesting that the $\mathrm{V}_{10}$ interaction with the proteins maybe favored by the existence of an ATP binding site [21,23,24]. In that sense, it is of particularly importance the study of the structure of decavanadate formation in the presence of organic compounds [25]. Moreover, decavanadate modulates voltage-dependent $\mathrm{Ca}^{2+}$-active cation channel [26], mimics noradrenaline action [27] and induces decavanadate reductase activity [28].

Vanadium is a heavy metal with increased environmental circulation, resulting from various anthropogenic activities [29-31] and it is of great concern due to its toxicity and accumulative behavior at specific target organs, such as the liver and kidney, inducing oxidative damage, lipid peroxidation and changes in haematological, reproductive and respiratory systems [32-36]. Formation of reactive oxygen species (ROS) induced by vanadium in biological systems may involve Fenton-like reactions [34], vanadate bioreduction mediated by reduced glutathione (GSH), flavoenzymes or nicotinamide adenine dinucleotide, reduced form (NADH), and nicotinamide adenine dinucleotide phosphate, reduced form, (NADPH) oxidases [37-39] or interaction with mitochondria [14].

In biological systems vanadium majority exists in anionic and cationic forms, the most common ones being vanadate $\left(\mathrm{H}_{2} \mathrm{VO}_{4}^{-}\right)$and oxovanadium $(\mathrm{IV})\left(\mathrm{VO}^{2+}\right)$ $[40,41]$. It is considered that almost $98 \%$ of vanadium in cells is present as vanadium $(+4)$ oxidation state (oxovanadium(IV)). Besides, the intracellular concentration of vanadium $(+5)$ (vanadate) is very low to vanadate oligomers be formed. Those are probably the reasons why in vivo toxicological studies of vanadate oligomers effects are scarce. However, it is proposed that once formed the rate of decavanadate decomposition is slow (half-life of $h$ ) enough to allow to study its effects not only in vitro, but also in vivo [42-45]. In fact, recently reported studies demonstrated that, after 1 and 7 days of in vivo administration, decavanadate species induces different effects, when compared to other oligomers, on anti-oxidant enzymes, lipid peroxidation, subcellular vanadium distribution and tissue damage in liver, kidney and heart [43-45]. In the present review, it is summarized these recent findings about the in vivo decameric vanadate effects besides the reported bio- chemical role on two energy transduction systems from skeletal muscle namely, sarcoplasmic reticulum calcium pump and myosin.

\section{Decameric species in vanadate solutions}

Vanadium (V) solutions contain different oligomeric $(n=1-10)$ vanadate species in equilibrium, e.g., monomeric $\left(\mathrm{V}_{1}\right)$, dimeric $\left(\mathrm{V}_{2}\right)$, tetrameric $\left(\mathrm{V}_{4}\right)$ and decameric $\left(\mathrm{V}_{10}\right)$ and in same cases, with different states of protonation and conformations [20]. Preparation of vanadate solutions containing decameric species have been developed to study the interaction and/or effects promoted by these species in proteins $[42,46-52]$.

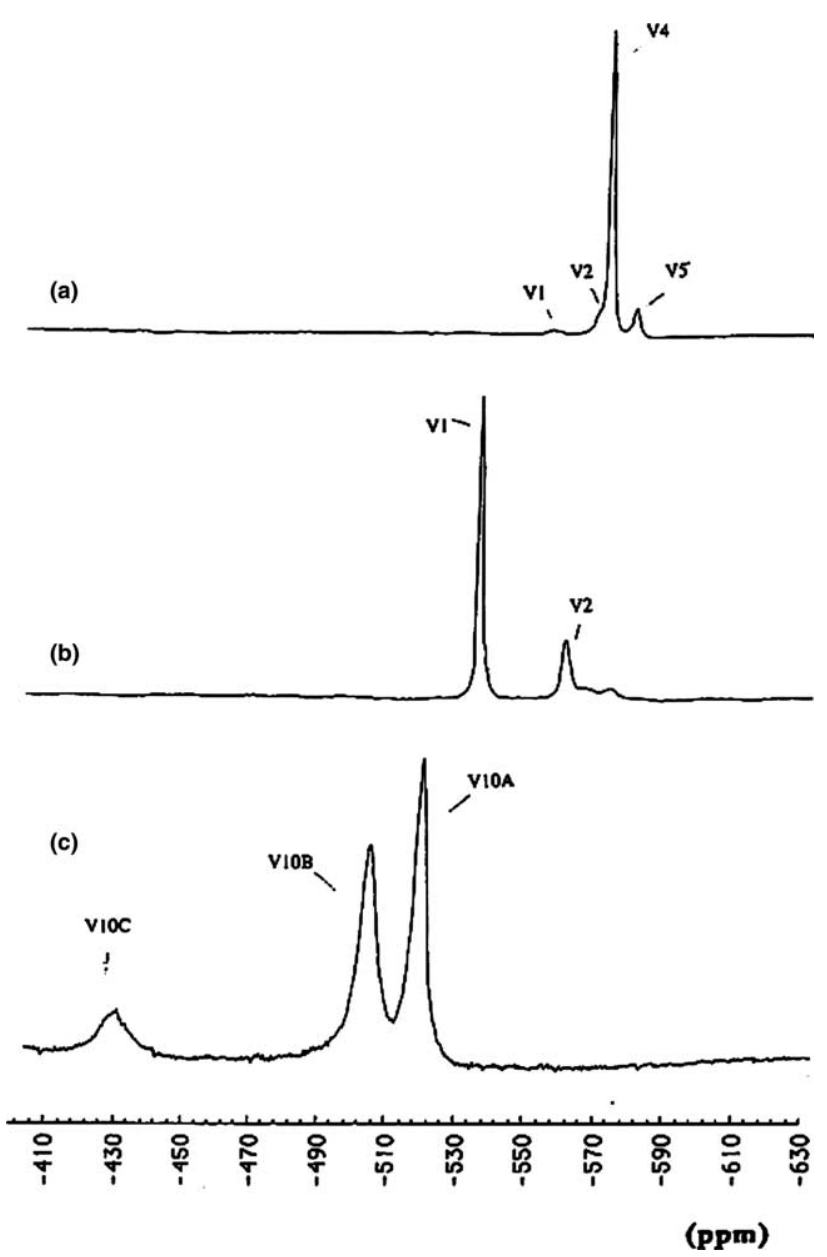

Fig. 1. $52.6 \mathrm{MHz}{ }^{51} \mathrm{~V}$ NMR spectra, at $22{ }^{\circ} \mathrm{C}$, of metavanadate (a and b) and decavanadate (c) stock solutions, $50 \mathrm{mM}$ in vanadium, prepared from ammonium metavanadate: (a) $\mathrm{pH} 6.7$; (b) $\mathrm{pH} 9.7$ and heated for $10 \mathrm{~min}$; (c) $\mathrm{pH} 4.0$. Vertical scale in (c) is amplified $4 \times . \mathrm{V}_{1}$ and $\mathrm{V}_{2}$ NMR signals correspond, respectively, to monomeric $\left(\mathrm{VO}_{4}^{3-}, \mathrm{HVO}_{4}^{2-}\right.$ and $\left.\mathrm{H}_{2} \mathrm{VO}_{4}^{-}\right)$and dimeric $\left(\mathrm{HV}_{2} \mathrm{O}_{7}^{3-}\right.$ and $\left.\mathrm{H}_{2} \mathrm{~V}_{2} \mathrm{O}_{7}^{2-}\right)$ vanadate species irrespectively of the protonation state. $\mathrm{V}_{10 \mathrm{~A}}, \mathrm{~V}_{10 \mathrm{~B}}$ and $\mathrm{V}_{10 \mathrm{C}}$ are signals of vanadium atoms from the decameric $\left(\mathrm{V}_{10} \mathrm{O}_{28}^{6-}\right)$ species. 


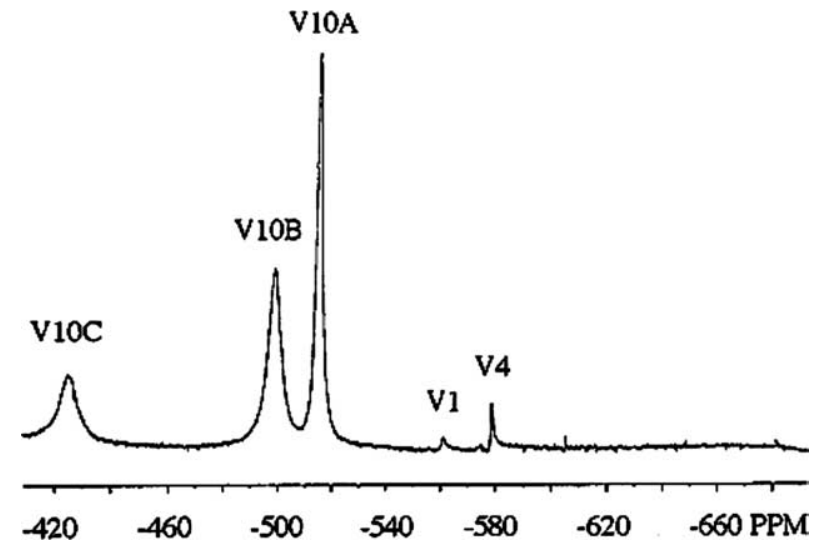

Fig. 2. $52.6 \mathrm{MHz}{ }^{51} \mathrm{~V}$ NMR spectra, at $22^{\circ} \mathrm{C}$, of a decavanadate stock solution $100 \mathrm{mM}$ in vanadium $(10 \mathrm{mM}$ in decavanadate), prepared from sodium orthovanadate, after adjusting the $\mathrm{pH}$ to 4.0 and than to 7.0. $\mathrm{V}_{1}$ and $\mathrm{V}_{2} \mathrm{NMR}$ signals correspond, respectively, to monomeric $\left(\mathrm{VO}_{4}^{3-}, \mathrm{HVO}_{4}^{2-}\right.$ and $\left.\mathrm{H}_{2} \mathrm{VO}_{4}^{-}\right)$and dimeric $\left(\mathrm{HV}_{2} \mathrm{O}_{7}^{3-}\right.$ and $\left.\mathrm{H}_{2} \mathrm{~V}_{2} \mathrm{O}_{7}^{2-}\right)$ vanadate species irrespectively of the protonation state. $\mathrm{V}_{10 \mathrm{~A}}, \mathrm{~V}_{10 \mathrm{~B}}$ and $\mathrm{V}_{10 \mathrm{C}}$ are signals of vanadium atoms from the decameric $\left(\mathrm{V}_{10} \mathrm{O}_{28}^{6-}\right)$ species.

In our laboratory there is a long tradition in the preparation of decavanadate solutions $[53,54]$. Twenty years ago, in 1985, it was demonstrated that the mode of preparation of vanadate solutions is determinant to obtain only decameric species (Fig. 1). It should be noted that often, vanadate solutions prepared from ammonium metavanadate contain decameric species probably due to an eventual acidification of the medium. To avoid the presence of decameric and other vanadate oligomers the vanadate solutions should be heated for $10 \mathrm{~min}$, at pH 10 (Fig. 1(b)). More recently, it has been focus that the denominated "decavanadate" stock solutions (containing presumably only decameric species) are also often contaminated with other species. In fact, as appraised by NMR spectroscopy, "decavanadate" stock solution $\mathrm{pH} 4.0,100 \mathrm{mM}$ in total vanadium, contains only $10 \mathrm{mM}$ of decameric species since only signals from decameric vanadate species are observed: $V_{10 \mathrm{~A}}$ at $-515 \mathrm{ppm}, \mathrm{V}_{10 \mathrm{~B}}$ at $-500 \mathrm{ppm}$ and $\mathrm{V}_{10 \mathrm{C}}$ at $-424 \mathrm{ppm}$ (Fig. 1(c)). When the $\mathrm{pH}$ is adjusted to 7.0, small amounts of mono $\left(\mathrm{V}_{1}\right)$ at $-560 \mathrm{ppm}$, di $\left(\mathrm{V}_{2}\right)$ at $-574 \mathrm{ppm}$ and tetrameric $\left(\mathrm{V}_{4}\right)$ species at $-578 \mathrm{ppm}$ were detected (Fig. 2). At room temperature, when this "decavanadate" solution is diluted into the reaction medium in the concentration range normally used in kinetic studies (up to $5 \mathrm{mM}$ in vanadium), the concentration of decameric vanadate increases linearly with total vanadate [42]. At this experimental condition, the rate of decomposition is slow (half-life of $5-15 \mathrm{~h}$ depending on the medium) allowing studying the effect of the decameric species in the activity of enzymes. However, at $37^{\circ} \mathrm{C}$, the disappearance of the 360 and $400 \mathrm{~nm}$ bands ascribed to decameric species is faster with half-life below $60 \mathrm{~min}$ [21].

\section{The iceberg phenomena: interactions and enzyme effects}

Often, the vanadate species variety is not accounted for consideration in most biological studies, although it is recognized that the individual species may differently influence enzyme activities [9-11,21,42]. Therefore, it is of primary importance to precisely characterize the vanadate species and the interactions with the system before attempting to understand the promoted effects. Allegorically, vanadate studies in biological systems are comparable to the iceberg phenomena: there is an invisible part, probably not the most interesting, but certainly the major.

The pioneer studies on the interaction between decavanadate and proteins were performed with ribonuclease, in 1973 [55]. These and other studies demonstrated the decavanadate species as potentially responsible for the effects promoted in enzyme activities [9]. With sarcoplasmic reticulum (SR) $\mathrm{Ca}^{2+}$-ATPase, decavanadate interacts particularly with the E2 conformation of the enzyme $[46,56]$, inducing crystallization of SR $\mathrm{Ca}^{2+}$-ATPase dimmers [57,58], mediating photocleavage [50,51], inhibiting ATP hydrolysis and $\mathrm{Ca}^{2+}$ accumulation [42], proton ejection associated with $\mathrm{Ca}^{2+}$ translocation [52], and both passive and active efflux of $\mathrm{Ca}^{2+}$ by the $\mathrm{Ca}^{2+}$ pump of sarcoplasmic reticulum [59].

SR $\mathrm{Ca}^{2+}$-ATPase is a transmembrane transport system, which accumulates $\mathrm{Ca}^{2+}$ at expense of ATP splitting during the process of muscle relaxation. The measurements of $\mathrm{Ca}^{2+}$ accumulation by the sarcoplasmic reticulum calcium pump reflect simultaneously the uptake of $\mathrm{Ca}^{2+}$ through the pump and the $\mathrm{Ca}^{2+}$ efflux. This efflux could be passive when not associated with the pump activity or active when directly associated with intrinsic reactions to the $\mathrm{SR} \mathrm{Ca}^{2+}$ pump mechanisms. Kinetic studies performed by radiometry shows that the accumulation of $\mathrm{Ca}^{2+}$ by the sarcoplasmic reticulum vesicles is strongly affected by decavanadate [59].

SR vesicles loaded with radioactive $\mathrm{Ca}^{2+}$, sediment by centrifugation and diluted into media containing ethylenebis(oxyethylenenitrilo)tetraacetic acid (EGTA), $\mathrm{Ca}^{2+}$ passively leaks through the ATPase. At this experimental condition the ATPase works as a channel and the oligomeric species of vanadate behave as natural ligands of the enzyme as observed before for ATPase natural ligands such as $\mathrm{Ca}^{2+}, \mathrm{Mg}^{2+}, \mathrm{K}^{+}$, adenosine $5^{\prime}$ diphosphate (ADP), $\mathrm{PO}_{4}^{3-}$ and $\mathrm{Na}^{+}$. When $\mathrm{SR}$ vesicles were diluted into media containing ADP and orthophosphate the $\mathrm{Ca}^{2+}$ efflux from the vesicles was strongly depressed $(85 \%)$ by $0.4 \mathrm{mM}$ vanadate "decavanadate", containing about $40 \mu \mathrm{M}$ decameric species". Thus, "decavanadate" exert noticeable effects when the efflux of $\mathrm{Ca}^{2+}$ is associated with adenosine 5'-triphosphate (ATP) synthesis, being the active efflux of $\mathrm{Ca}^{2+}$ is almost completely inhibited by "decavanadate" even for decameric species concentration as low as $40 \mu \mathrm{M}$ [59]. 
Decameric vanadate has been shown to have a stronger affinity for SR ATPase relatively to other oligomeric species [46]. It was initially reported that decameric species might bind to the ATPase at the vicinity of the phosphate acceptor (351 aspartyl residue), thus blocking the active site by preventing formation of the phosphoenzyme intermediate [47]. The decameric vanadatebinding site to the enzyme has been referred as the ATP binding site [47] or very close to it [51] in addition to the binding site for monomeric species $[47,48]$. By using small concentrations of "decavanadate" and experimental conditions minimizing the contamination from others species, it has been suggested that the decameric species may bind to the SR ATPase after ATP binding, whereas the appearance of monomeric species induce decameric to compete with ATP [21]. It was observed that by increasing the "decavanadate" concentration SR calcium pump inhibition changes from uncompetitive to non-competitive regarding ATP [21]. Decavanadate may bind at or near the nucleotide site and involves Ser186 at the small cytosolic loop (A-domain) of the $\mathrm{Ca}^{2+}$-ATPase [60]. Moreover, we recently verified that in the presence of $5 \mu \mathrm{M} \mathrm{SR} \mathrm{Ca}^{2+}$-ATPase the half-life of decameric vanadate, as low as $10 \mu \mathrm{M}$ decameric species $(100 \mu \mathrm{M}$ total vanadate), increases from 5 to $18 \mathrm{~h}$, at room temperature and $\mathrm{pH} 7.0$, as appraised by UV/vis at $400 \mathrm{~nm}$. Therefore, apparently, the disintegration of decameric vanadate follows a first order kinetic, independent of concentration, being prevented by ATPases with high affinity to $V_{10}$.

Vanadate monomer, can act as a ground state or transition state analogue of inorganic phosphate, which has made this ion a valuable tool for studying enzymecatalyzed phosphotransferases and phosphohydrolases reactions $[5,9]$. This is particular relevant for myosin (M), the major ATPase of muscle, that is strongly inhibited by vanadate. The head segment of myosin, called subfragment 1 (S1), contains the binding sites for ATP and actin, and is responsible for the ATPase activity during the process of muscle contraction [61]. The binding of ATP reduces the affinity of myosin for actin, and the subsequent hydrolysis of ATP results in a ternary complex between myosin, ADP and inorganic phosphate $\left(\mathrm{P}_{\mathrm{i}}\right)$. The rate-limiting step of the ATP hydrolysis is the release of $\mathrm{Pi}$ from myosin, which is accelerated by the rebinding of actin. Vanadate inhibits myosin ATPase activity by forming, in the absence of actin, a very stable complex with MgADP that mimic either the transition state of hydrolysis or ADP - Pi intermediate state [62].

Original findings that decameric also affect the myosin ATPase activity and that the inhibitory effects are restricted to some of the species were reported $[22,63,64]$. It has been proposed that $\mathrm{V}_{10}$ bind to myosin via the "back door" to form a more stable $\mathrm{V}_{10}$ myosin complex, although the mechanism of interaction is still to be clar- ify. However, this $\mathrm{V}_{10}$ high affinity-binding site produces non-competitive inhibition of the actin stimulated S1ATPase activity, without causing dissociation of the acto-S1 complex [22]. Additionally, it was demonstrated unambiguously the residues undergoing photocleavage on myosin by the decameric vanadate $\left(\mathrm{V}_{10}\right)$ [65]. Two putative binding sites one of higher affinity located on the 178-185 sequence (loop-P) which forms the consensus ATP binding site of myosin and another one of lower affinity from residues 627-646 (loop-2), which makes part of the actin-binding interface were proposed. Suggested location of the myosin subfragment-1 high affinity binding site for decameric vanadate species points to the S1 surface area bearing myosin segments 141-150, 180-190 and/or 706-726 which contains a total of 13 positively charged amino acids (Lys + Arg) and only 2 negatively charged amino acids (Asp + Glu) (unpublished results). Another important result is that $\mathrm{V}_{10}$ and $\mathrm{V}_{4}$ bind to the same protein binding site(s), although its interactions are differently modulated by the myosin natural ligands (ATP and actin). $\mathrm{V}_{10}$ appears not to be affected by the products release during ATP hydrolysis, as shown by the NMR experiments. In addition, $V_{10}$ has a greater affinity for myosin binding sites than $\mathrm{V}_{4}$ in the same way that, $\mathrm{V}_{4}$ has a greater affinity than the lower vanadate oligomers, which can be explained if electrostatic forces play an important role in vanadate interaction with proteins that binds $V_{10}$ such as myosin, sarcoplasmic reticulum calcium pump and other nucleotide binding enzymes [21,23,24,26-28]. In that sense, $V_{10}$ may contribute to the inhibition of actin-stimulated myosin ATPase activity, through binding at the myosin phosphate loop. Therefore, even if $\mathrm{V}_{10}$ is not likely to be present at significant concentrations under physiological conditions, it has revealed a useful biochemical tool not only for the description of the location and function of the phosphate binding sites on myosin, but also for the molecular interpretation of actomyosin interactions and consequently for muscle contraction regulation $[22,66]$.

\section{In vivo decavanadate effects}

As described above, several studies report that "decavanadate" has a stronger inhibitory effect on several enzymes, when compared to other vanadate oligomers. Besides, decameric vanadate binding with specific proteins may prevent its disintegration. However, only a few studies consider the hypothesis of a possible effect of decavanadate at physiological conditions since, in these conditions, vanadate is considered to be reduced to oxovanadium(IV) and "decavanadate" concentration is very low or is not present for long enough to induce any effects [67-70]. In order to relate the effects observed in vivo with the decavanadate present in solution, we 
studied its stability in the injected solution and it was observed that the half-life for decameric vanadate species on "decavanadate" solution is about $10 \mathrm{~h}$, at room temperature. Our group have studied the in vivo effect of decavanadate, in vanadium accumulation in Halobatrachus didactylus $[43,71]$ and in Spaurus aurata [72], in several oxidative stress markers in the cardiac [43] and hepatic tissues [71], in the metahaemoglobin reductase activity [45] and in the histology of heart, kidney, and liver of Halobatrachus didactylus [44], comparing the injection of two vanadate solutions, "decavanadate" and "metavanadate", containing different oligomeric species.

In fact, when decavanadate was administered a different fate of intracellular vanadium accumulation is observed. Seven days after decavanadate administration, the vanadium content in the cytosolic fraction from cardiac tissue was 4 times increased $(p<0.05)$ while no increase was registered in metavanadate-administered individuals, whereas both solutions increase up to 3 times the mitochondrial vanadium content [43]. In hepatic tissue, decavanadate solution promotes a 5-fold increase $(p<0.05)$ in the vanadium content of the mitochondrial fraction 7 days after exposure while no effects were observed after metavanadate solution administration [71]. Also, decavanadate induces different patterns of subcellular vanadium distribution in blood plasma, red blood cells (RBC) and cardiac muscle subcellular fractions of the fish Sparus aurata (gilthead seabream), being vanadium mainly distributed in plasma, before accumulated into the mitochondrial fraction [72].

It was recently demonstrated that decavanadate induce stronger effects than metavanadates in the activity of anti-oxidant enzymes and in lipid peroxidation of cardiac tissue. The acute exposure to decavanadate increases the oxidative stress, by depressing the activity of anti-oxidant enzymes (catalase, superoxide dismutase and glutathione peroxidase) and increasing the lipid peroxidation in the cardiac tissue of Halobatrachus didactylus [43]. In the hepatic tissue, the overall oxidative stress was not increased, but the mitochondrial superoxide anion production and the lipid peroxidation was increased after "decavanadate" solution administration [71]. It was demonstrated that the administration of decameric vanadate species induces different effects in hepatic and cardiac oxidative stress markers when we compared with other vanadate oligomers. All this data support the hypothesis that mitochondria might be a target for decameric vanadate species. Also, methaemoglobin reductase activity was affected differently after the administration of "decavanadate" or "metavanadate" solutions, metavanadate induced an increase of enzymatic activity, while in the presence of decavanadate no significant changes were observed [45]. Decavanadate was reported to induce hypertrophy of the ventricle due to a decrease in the percentage of myocardium occupied by collagen fibers [44].

Several suggestions on vanadate relation with ROS were made so far; nonetheless more work is needed to clarify whether vanadate speciation in vivo, its reduction, its action mechanisms and pathways could have different physiologic roles. One thing is becoming clear, decavanadate seems to follow, not only in vitro but also in vivo, different pathways, with different targets and effects than other vanadate oligomers. Decameric vanadate is not normally considered biological studies, but due to its stability at physiologic conditions, it may not be completely disintegrated into other vanadate oligomers before induces changes in several stress markers.

\section{Conclusions}

This review focuses the fact that decavanadate may occur simultaneously with others oligomeric species in vanadate solutions and therefore, it is important to understand their contributions to vanadium toxicity. Decavanadate species, present in vanadium (V) solutions, contributed to the effects induced by vanadate on phosphohydrolases and ATPases such as the $\mathrm{Ca}^{2+}$. pump of sarcoplasmic reticulum and myosin of skeletal muscle. Decameric vanadate biological effects are tight related with these energy transduction systems, once specific interactions and different effects were described. Current studies are in progress in order to understand the role of decavanadate in the modulation of muscle contraction. Moreover, decavanadate in vivo intoxication clearly induces different changes on oxidative stress markers and lipid peroxidation than others oligomers. Upon intoxication with decavanadate, the metabolism of vanadium is affected being mitochondria a potential target. Although decameric vanadate is not normally considered in biological studies, due to its stability at physiologic $\mathrm{pH}$, it is suggested that it may not completely fall apart into other vanadate oligomers before induces changes in cell homeostasis, namely in several stress markers. These results point out to the importance of taking into account decavanadate in the evaluation of vanadium biological effects. It is believed that the progress in understanding the role and the contribution of decavanadate to vanadium biological effects may be useful to gain a deeper knowledge in vanadium biochemistry (Fig. 3). Questions that remain to be addressed include for instance: (i) How is decavanadate taken up into cells? (ii) Can it be formed in intracellular medium? (iii) Which are the molecular and subcellular targets of $\mathrm{V}_{10}$ with physiological relevance? (iv) Is oxidative stress induced by decavanadate due to its decomposition? (v) Can ATPases be modulated by decavanadate? (vi) How can decavanadate bind tightly to myosin and 


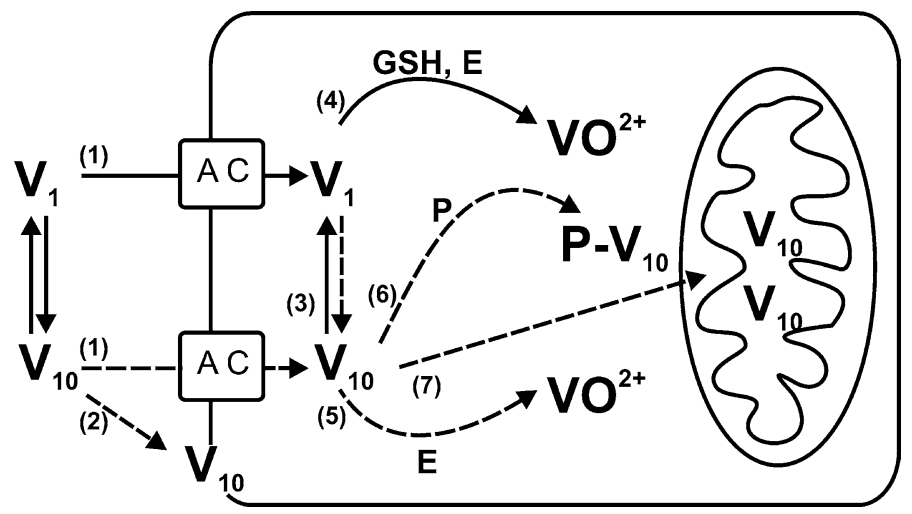

Fig. 3. Scheme of the proposed cellular targets of decavanadate $\left(\mathrm{V}_{10}\right)$ : (1) $\mathrm{V}_{10}$ uptake through anionic channels; (2) $\mathrm{V}_{10}$ binding to membrane proteins; (3) formation of $\mathrm{V}_{10}$ upon intracellular acidification; (4) reduction of monomeric vanadate by antioxidant agents; (5) reduction of decameric vanadate by enzymes; (6) binding of $\mathrm{V}_{10}$ to target proteins preventing its reduction; and (7) accumulation $\mathrm{V}_{10}$ into subcellular organelles such as mitochondria. $\mathrm{V}_{10}$, decameric vanadate; $\mathrm{V}_{1}$, monomeric vanadate; $\mathrm{E}$, enzyme; $\mathrm{P}$, protein; AC, anionic channel; $\mathrm{VO}^{2+}$, oxovanadium(IV) bound to a bioligand.

prevent actomyosin dissociation? (vii) Are there other myosin domains affected by decavanadate?

\section{Acknowledgment}

M. Aureliano thanks Portuguese Foundation for Science and Technology (FCT); POCTI program financed through FEDER; the University of Algarve, research project POCTI: 38191/QUI/2001 and Cost D21.

\section{References}

[1] L. Josephson, L.C. Cantley Jr., Biochemistry 16 (1977) 45724578.

[2] L.A. Beaugé, I.M. Glynn, Nature 272 (1978) 551-552.

[3] L.C. Cantley Jr., L. Josephson, R. Warner, M. Yanagisawa, C. Lechene, G. Guidotti, J. Biol. Chem. 252 (1977) 7421-7423.

[4] P.L. Pedersen, E. Carafoli, Trends Biochem. Sci. 12 (1987) 146150.

[5] D.R. Davies, W.G.J. Hol, FEBS Lett. 577 (2004) 315-321.

[6] B. Desoize, F. Briois, Y. Carpentier, Int. J. Oncol. 5 (1994) 87-91.

[7] M. Colin, C. Madoulet, N. Baccard, F. Arsac, J.C. Jardillier, Anticancer Res. 14 (1994) 2383-2388.

[8] Y. Shechter, Diabetes 39 (1990) 1-5.

[9] N.D. Chasteen, Struct. Bond. 53 (1983) 105-138.

[10] D.C. Crans, Comments Inorg. Chem. 16 (1994) 35-76.

[11] P.J. Stankiewicz, A.S. Tracey, D.C. Crans, in: H. Sigel, A. Sigel (Eds.), Metal Ions in Biological Systems: Vanadium and Its Role in Life, Marcel Dekker, New York, 1995, pp. 287-324.

[12] G. Heinemann, B. Fichtl, W. Vogt, Br. J. Clin. Pharmacol. 55 (2003) 241-245.

[13] H. Sakurai, T. Inohara, Y. Adachi, K. Kawabe, H. Yasui, J. Takada, Bioorg. Med. Chem. Lett. 14 (2004) 1093-1096.

[14] X.G. Yang, X.D. Yang, L. Yuan, K. Wang, D.C. Crans, Pharm. Res. 21 (2004) 1026-1033.

[15] P.S. Kanna, C.B. Mahendrakumar, B.N. Indira, S. Srivastawa, K. Kalaiselvi, T. Elayaraja, M. Chatterjee, Environ. Mol. Mutagen. 44 (2004) 113-118.

[16] M.S. Molinuevo, D.A. Barrio, A.M. Cortizo, S.B. Etcheverry, Cancer Chemother. Pharmacol. 53 (2004) 163-172.
[17] O.J. D’Cruz, Y. Dong, F.M. Uckun, Biochem. Biophys. Res. Commun. 302 (2003) 253-264.

[18] B.R. Nechay, L.B. Nanninga, P.S.E. Nechay, R.L. Post, J.J. Grantham, I.G. Macara, L.F. Kubena, T.D. Philipps, F.H. Nielsen, Fed. Proc. 45 (1986) 123-132.

[19] B.F. Harland, B.A. Harden-Williams, J. Am. Diet. Assoc. 94 (1994) 891-894.

[20] A.M. Amado, M. Aureliano, P.J. Ribeiro-Claro, J.J.C. TeixeiraDias, J. Raman Spectroscopy 24 (1993) 669-703.

[21] M. Aureliano, V.M.C. Madeira, in: J.O. Nriagu (Ed.), Vanadium in the Environment. Part 1: Chemistry and Biochemistry, John Wiley, New York, 1998, pp. 333-357.

[22] T. Tiago, M. Aureliano, C. Gutiérrez-Merino, Biochemistry 43 (2004) 5551-5561.

[23] R.J. Pezza, M.A. Villarreal, G.G. Montich, C.E. Argarana, Nucleic Acids Res. 30 (2002) 4700-4708.

[24] J.M. Messmore, R.T. Raines, Arch. Biochem. Biophys. 381 (2000) 25-30.

[25] I. Correia, F. Avecilla, S. Marcão, J.C. Pessoa, Inorg. Chim. Acta 357 (2004) 4476-4487.

[26] B. Nilius, J. Prenen, A. Janssens, T. Voets, G. Droogmans, J. Physiol. 560 (2004) 753-765.

[27] B.V. Venkataraman, H.N. Ravishankar, A.V. Rao, P. Kalyani, G. Sharada, K. Namboodiri, B. Gabor, T. Ramasarma, Mol. Cell Biochem. 169 (1997) 27-36.

[28] A.V. Rao, T. Ramasarma, Biochim. Biophys. Acta 1474 (2000) $321-330$.

[29] J.O. Nriagu, in: J.O. Nriagu (Ed.), Vanadium in the Environment. Part 1: Chemistry and Biochemistry, John Wiley, New York, 1998, pp. 1-24.

[30] M.U. Beg, S. Al-Muzaini, T. Saeed, P.G. Jacob, K.R. Beg, M. Al-Bahloul, K. Al-Matrouk, T. Al-Obaid, A. Kurian, Arch. Environ. Contam. Toxicol. 41 (2001) 289-297.

[31] T. Grahame, G. Hidy, Inhal. Toxicol. 1 (2004) 143-152.

[32] L. Zychlinski, J.Z. Byczkowski, A.P. Kulkarni, Arch. Environ. Contam. Toxicol. 20 (1991) 295-298.

[33] H. Zaporowska, W. Wasilewski, Comp. Biochem. Physiol. 102 (1992) 223-231.

[34] S. Stohs, D. Bagchi, Free Radic. Biol. Med. 18 (1995) 321-336.

[35] J.L. Domingo, Reprod. Toxicol. 10 (1996) 175-182.

[36] J.Z. Byczkowski, A.P. Kulkarni, in: J.O. Nriagu (Ed.), Vanadium in the Environment. Part 1: Chemistry and Biochemistry, John Wiley, New York, 1998, pp. 235-263.

[37] E.G. Ferrer, P.A.M. Williams, E.J. Baran, J. Inorg. Biochem. 50 (1993) 253-262. 
[38] Z. Zhang, C. Huang, J. Li, S.S. Leonard, R. Lanciotti, L. Butterworth, X. Shi, Arch. Biochem. Biophys. 392 (2001) 311-320.

[39] L. Capella, M. Gefé, E. Silva, E. Affonso-Mitidieri, A. Lopes, V. Rumjanek, M. Capella, Arch. Biochem. Biophys. 406 (2002) 65-72.

[40] D. Rehder, BioMetals 5 (1992) 3-12.

[41] M. Garner, J. Reglinski, W.E. Smith, J. McMurray, I. Abdullah, R. Wilson, J. Biol. Inorg. Chem. 2 (1997) 235-241.

[42] M. Aureliano, V.M.C. Madeira, Biochim. Biophys. Acta 1221 (1994) 259-271.

[43] M. Aureliano, N. Joaquim, A. Sousa, H. Martins, J. Coucelo, J. Inorg. Biochem. 90 (2002) 159-162.

[44] G. Borges, P. Mendonça, N. Joaquim, J. Coucelo, M. Aureliano, Arch. Environ. Contam. Toxicol. 45 (2003) 415-422.

[45] S.S. Soares, M. Aureliano, N. Joaquim, J. Coucelo, J. Inorg. Biochem. 94 (2003) 285-290.

[46] P. Csermely, A. Martonosi, G.C. Levy, A.J. Ejchart, Biochem. J. 230 (1985) 807-815.

[47] S. Varga, P. Csermely, A. Martonosi, Eur. J. Biochem. 148 (1985) 119-126.

[48] P. Csermely, S. Varga, A. Martonosi, Eur. J. Biochem. 150 (1985) 455-460.

[49] C. Coan, D.J. Scales, A.J. Murphy, J. Biol. Chem. 261 (1986) 10394-10403.

[50] M. Vegh, E. Molnar, A. Martonosi, Biochim. Biophys. Acta 1023 (1990) 168-183.

[51] E. Molnar, S. Varga, A. Martonosi, Biochim. Biophys. Acta 1068 (1991) 17-26.

[52] M. Aureliano, V.M.C. Madeira, Biochem. Biophys. Res. Commun. 205 (1994) 161-167.

[53] M. Aureliano, Biochemistry, Graduation thesis, University of Coimbra, 1985.
[54] M. Aureliano, Cell Biology, M.Sc. thesis, University of Coimbra, 1991.

[55] E.G. DeMaster, R.A. Mitchell, Biochemistry 12 (1973) 26163621.

[56] P. Medda, W. Hasselbach, Eur. J. Biochem. 137 (1983) 7-14.

[57] L. Dux, A. Martonosi, J. Biol. Chem. 258 (1983) 2599-2603.

[58] A. Maurer, S. Fleischer, J. Bioenerg. Biomembr. 16 (1984) 491505.

[59] M. Aureliano, J. Inorg. Biochem. 80 (2000) 145-147.

[60] S. Hua, G. Inesi, C. Toyoshima, J. Biol. Chem. 275 (2000) 3054630550.

[61] R.W. Lymn, E.W. Taylor, Biochemistry 10 (1971) 4617-4624.

[62] C.C. Goodno, Methods Enzymol. 85 (1982) 116-123.

[63] M. Aureliano, J. Inorg. Biochem. 80 (2000) 141-143.

[64] T. Tiago, M. Aureliano, R.O. Duarte, J.J.G. Moura, Inorg. Chim. Acta 339 (2002) 317-321.

[65] T. Tiago, M. Aureliano, J.J.G. Moura, J. Inorg. Biochem. 98 (2004) 1902-1910.

[66] T. Tiago, M. Aureliano, C. Gutiérrez-Merino, J. Fluorescence 12 (2002) 87-90.

[67] J. Edel, E. Sabbioni, Sci. Tot. Environ. 133 (1993) 139-151.

[68] X. Yang, K. Wang, J. Lu, D.C. Crans, Coord. Chem. Rev. 237 (2003) 103-111.

[69] E. Baran, in: J.O. Nriagu (Ed.), Vanadium in the Environment, Part 2, Health Effects, John Wiley, New York, 1998, pp. 318-345.

[70] B. Hasspieler, J. Behar, R. Di-Giulio, Ecotox. Environ. Saf. 28 (1994) 82-90.

[71] R.M.C. Gândara, S.S. Soares, H. Martins, C. Gutiérrez-Merino, M. Aureliano, J. Inorg. Biochem., in press.

[72] S.S. Soares, H. Martins, M. Aureliano, Arch. Environ. Contam Toxicol., accepted. 